\title{
Price Tag on a College Library
}

BY ANDRE NITECKI

$\mathrm{T}$ he ARTICLE "Price Tag on a University Library" by Robert B. Downs and Robert F. Delzell ${ }^{1}$ prompted me to evaluate the cost of develcping a college library. It seems to me very useful to have a financial appraisal of a new and small library, especially of a library that does not hold rare material or special collections. It appears correct to presume that there are hundreds of college libraries that fall into this category and hundreds more that will come into existence in the near future. Therefore, it is obvious that such an estimate can be helpful to a college administration planning a budget for its new library, to a college trying to increase its library collection, or as a guide in insuring a library.

For this study the library holdings and expenditures of two small colleges, Flint College of the University of Michigan and the Flint Junior College, were examined.

Both Flint Junior College and Flint College are relatively young institutions. The Junior College was established in 1923, Flint College of the University of Michigan in 1956. Their campuses are contiguous and though the library of each has built its own collection, they have been both under the directorship of James W. Pirie since 1957. In 1960 the two libraries were merged into one with a combined collection of 55,328 volumes.

During its four years as the library of a single institution, the library of Flint College built a collection of 25,871 volumes.

The estimated cost of preparing the collection for use was $\$ 190,360.00$ :

1 CRL, XXI (1960), 359-361.
Mr. Nitecki is Director of Technical Processes at the Flint College Library, Flint, Mich.

Expenditure for books (25,781 volumes)

$\$ 79,577.00$

Estimated value of gifts received $1956 / 60^{2}$

$36,466.00$

Total salaries for the technical processes department

$74,317.00$

Total

$\$ 190,360.00$

At the end of 1959/6o fiscal year the total holdings of Flint Junior College's library were 29,547 volumes. The estimated cost of preparing the collection for use was $\$ 271,267.28$ :

Expenditure for books (29,547 volumes)

$\$ 133,964.28$

Estimated value of gifts received $1942 / 60^{3}$

$37,739.00$

Total salaries for the technical processes department

$99,564.00$

Total

$\overline{\$ 271,267.28}$

The merger of the two libraries created a single collection of 55,328 volumes and an estimated value of $\$ 461,627.28$ :

Flint College of the

Holdings Estimated in volumes value

University of

Michigan Library $25,781 \quad \$ 190,360.00$

Flint Community

Junior College

Library 29,547

$271,627.28$

Total

55,328

$\$ 461,627.28$

The estimated value, was derived by addition of actual expenditures involved

$2 \$ 6.24$ per volume was used as an evaluation in estimating the gifts received. 
in acquisition and processing with an estimated worth of gifts received. Since those figures represent the prices and salaries during the years, it is advisable to estimate also the budget required to build a comparable collection in 1960 . To do this it is necessary to arrive at the cost of ordering, receiving, and cataloging as well as the average price of books acquired during 1959/60 fiscal year. The cost of adding a volume to the existing collection is estimated as $\$ 9.63$ :

Average price (after discounts)

Cost of ordering and receiving

Cost of cataloging (and end-processing

Cost of material (cards, glue, etc.)

TOTAL

$\$ 6.24$ per volume

1.31 per volume

1.99 per volume

.09 per volume

$\$ 9.63$ per volume

The above figures were the same for both libraries.

Using these figures it is calculated that in order to replace the collection of 55,328 volumes in 1960 it would have been necessary to spend $\$ 532,808.64$ :

Estimated cost of books (55,328 volumes@\$6.24

$\$ 345,246.72$

Estimated salaries 4 and materials@\$3.39 a volume

$187,561.92$

Total

$\$ 532,808.64$

The amount of $\$ 532,808.64$ needed to build a collection in one year is $\$ 71$,181.36 more than was actually spent to acquire the collection during the last eighteen years (actually spent by both libraries: $\$ 461,627.28$.)

Neither of the estimates takes into account the value of a physical plant or the cost of setting up an efficient operation. It is virtually impossible to estimate how much it would cost to train the staff nor how long it would take to accomplish the training.

4 The staff includes two professional librarians, four clerical personnel and 20 hours of student assistants a week.

\section{A Staff Librarian Views the Problem}

(Continued from page 281)

judge the library in terms of its staff. .. If the professional library personnel are in some nondescript category, without clearly defined status, with no institutional understanding of the contributions which they can make to the educational program, and placed outside, or made ineligible for, the usual academic perquisites and prerogatives, we can be ... certain that the library is inferior, falling far below its potentialities.... The institution can pay its money and take its choice." 13

It does not seem feasible to advocate a blanket acceptance of college librarians as academic faculty members at this time.

13 Robert B. Downs, "Are College and University Librarians Academic?" CRL, XV (1954), 10.
The identity which most staff librarians would presently aim for is rather "any satisfactory status." That is, a status recognizing the close link between librarians and teaching faculty, a niche symbolizing honestly the education and achievements of the librarian as an intellectual person contributing substantially toward the total college program. It is a transitional stage looking forward to the day when the college librarian will in all cases, beyond a doubt, be as thoroughly qualified and esteemed as his colleague in the teaching ranks. It is a status which expresses a positive idea, fruitful for the entire college world, saying "We, the academic community, base our evaluation of you, the librarian, on what you are, rather than on what you are not."

COLLEGE AND RESEARCH LIBRARIES 